\title{
Motorcycle Parking Design with Simulation Approach Case Study: Rusunawa Penjaringan Sari 3, Surabaya
}

\author{
Yohanes R. Krisnanda ${ }^{1}$, Indri Hapsari ${ }^{*}$, Jerry A. Arlianto ${ }^{1}$, Anton J. Tjahjoanggoro ${ }^{2}$, Markus Hartono ${ }^{1}$, Marselius $\mathrm{S}$. \\ Tondok ${ }^{2}$ \\ ${ }^{1}$ Universitas Surabaya, Industrial Engineering, Raya Kalirungkut, Surabaya, Indonesia \\ ${ }^{2}$ Universitas Surabaya, Faculty of Psychology, Raya Kalirungkut, Surabaya, Indonesia
}

\begin{abstract}
Rusunawa Penjaringan Sari 3 is flats owned by Surabaya City government with capacity 99 units. The current motorcycle parking lot has a total area $185.61 \mathrm{~m}^{2}$ and the parking slot dimension is $2 \mathrm{~m} \mathrm{X} 0.7 \mathrm{~m}$. It can accommodate 100 until 145 motorcycles. This limitation space makes motorcycles must park randomly and irregularly, such as parking at the space for people walking and parking in parallel that can block a motorcycle that wants to go out. Improvements that we did for parking layout in this research is based on parking standard, published by Indonesia Directorate General of Land Transportation. Each motorcycle has parking alternative slot dimension $2 \mathrm{mx} 0.85 \mathrm{~m}$ and the aisle width is $1.6 \mathrm{~m}$ and double way. Using simulation approach by ProModel, we developed 4 alternatives and compared them. The average time for residents to de-park until leave from parking space motorcycles decreased from 56.118 seconds to 17.342 seconds (alternative 1), 17.2273 seconds (alternative 2), 21.986 seconds (alternative 3 ), and 17.242 seconds (alternative 4).
\end{abstract}

\section{Introduction}

Rusunawa Penjaringan Sari 3 is a flat that established since 2010 and have aims to provide temporary shelter for residents as a victim of evictions. They can rent the unit and pay each month. This five floors building have capacity 99 units. Most of the occupants use motorcycle to support their mobility, and each unit may have more than one motorcycles. Total motorcycle residents recorded through observation and interview to each unit are 145 motorcycles and they are divided in two areas of parking. The first parking area is below the building with dimension $20 \mathrm{~m} \mathrm{x}$ $4.8 \mathrm{~m}$ and the capacity is 58 motorcycles, while another parking area is located outside the building with dimension of $15.45 \mathrm{~m} \times 5.80$ mand enough for 42 motorcycles. Due to the capacity of those parking area that only for 100 motorcycles, makes 45 motorcycles must park in parallel or in places that prohibited for parking. A good planning is needed to develop a new parking area that can accommodate the entire motorcycles and make the driver easier to park and de-park properly in available slots. When we observed at parking area, the aisle width in a narrow parking area is about 1 meter and the parking slot design is not complied with the standards of parking facilities. This is the root problem why the driver has trouble to park in parking area. The current parking slot dimensions is $2 \mathrm{~m} \mathrm{x}$ $0.7 \mathrm{~m}$, that is not fit with the standard.

In this research we developed alternatives for parking space with objectives to expand the capacity, faster park and de-park process, also offer the best alternative based on benefit cost ratio. We compared the result using simulation methods to see how our arrangement will work in certain conditions. Simulation is used because it can be solution for the problem. It is saving money, time and people because it is done by trial and error process. It can give capabilities and accuracy for the performance in complex system, it has strength as decision maker, give freedom to try different idea for result improvement, reduce the risk, time and destructive effect.

\section{Literature review}

Building parking lot for motorcycles requires variety of considerations and considers the standards that will guarantee sense of comfort and safety for the vehicle owner [1] namely:

1. Developers who build parking area should ensure the capacity and requirement based on Minnesota Asphalt Pavement Association. Some alternatives that can be used to maximize the parking area are:

- Use rectangular shape

- Use parallel long side

- The second parking lane path should not interfere vehicle entrance and exit

- The exit should not close to the current crowded streets

2. Angle parking that used to park vehicles. In general, the angle used is $60^{\circ}$ to make it easier in enter and exit parking slot. Motorcycles that park in Penjaringan Sari 3 use $90^{\circ}$ for more optimal utilization of parking space. However, this arrangement will make the

\footnotetext{
* Corresponding author: ihapsari@gmail.com
} 
driver more difficult to park and de-park from the parking slot.

3. The dimensions of the parking area. Some dimensions that must be taken into account, such as:

- The width and length of slot the parking vehicles must adapt the vehicle types. The motorcycle dimension parking slot that refers to the Directorate General of Land Transportation/ Direktorat Jenderal Perhubungan Darat [2] is 0.75 $\mathrm{m} \times 2 \mathrm{~m}$.

- Pay attention to the angle of the parking slot to make easier for the rider to access the motorcycle.

- The width to enter and exit along the parking area should be double way.

4. Signs/markers in the parking area. Providing sign/marker can give convenience to park and de-park every time. In general, marker of parking slot is line with the color white and yellow to give sign as a warning. Marker line must have 4-inch wide. For motorcycles in group could give a special color on the parking slot, for example blue for special needs or physical disability.

5. The security of the parking area [3]. Security is an important factor for the parking area which guarantee the safety to the vehicle owner. Some security alternatives for parking area are:

- Lighting

- Security cameras/CCTV.

- Barrier gate to enter and exit from the parking area and it can only be accessed by occupants who has vehicle license.

To support the design of parking layout, this research needs simulation to run the model and compare the result. According to Kakiay [4] simulation modeling needs to consider three essential elements, namely: System(system)is a group of components or entities like human and machine that interact and act together to achieve the ultimate goal that is logical [5].

a. Entity(entities) is the items to be processed by the system (Arifin,2009). Entities are divided into several forms, including animate like customers or patients, lifeless like part or documents, and cannot be touched like technology advances that change physical letter to electronic mail(e-mail).

b. Attributes(attributes) is everything becomes the property of the entity.

In the process of simulation, model can deliver maximum results for the current state and for the future. The approach of real systems will be a conceptual model, but if it continues to simulation as experiment, it will get real data. Predictive approach comes from comparison result on real condition and new layout to find and analyze the differences [6]. For simulation steps in Figure 1 will start from step 1 which is define the object, set the limitations and requirements of the problem. Requirements needed to determine the resources, time, and costs to run the simulation project. Step 2 is to collect and analyze data from the real system. The results of this step is a conceptual model. In the step 3 create a simulation model for real system. Step 4 will validate the simulation model. The models will be checked and make sure that it describes the real system. Step 5 is conducting experiments by running simulations for each scenario of the model, then evaluates and analyzes the results. Last is step 6 to deliver the results. It will provide solutions or recommendations from the simulation results. Simulation will be used to evaluate parking space availability for existing layout and new layout design. By using simulation, the new design can accommodate more capacity [7].

Almost all the real condition from a problem can be modelled by simulation. Some requirements that must be fulfilled are the operational have implemented, the process easy to visualize and repeated, the activities are independent and various, the cost to decide and to invest is very big. System that is learn well will give a good model, so in simulation and real condition the model can give maximum result. Based on the concept in system, there are three simulation approach. Approach to real system will develop a conceptual model, but if it is learnt by experiment we will get real data. The other is simulation model approach by developing the model from real system and by simulating it. The prediction approach come from comparison real data and simulation data to see the difference between real condition and simulation model after the improvement.

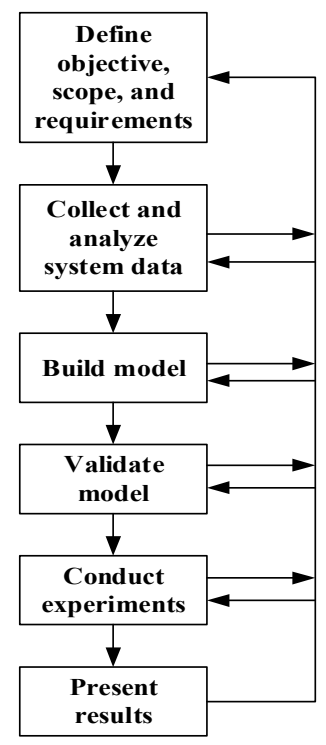

Fig. 1. Simulation Procedure [8]

Simulation model is visualization from real condition that will be analized to get the maximum result. In describing real system into the model, there is a possibility some mistakes were happened. The mistake is incompatibility between the simulation model and real condition, so the mocel cannot represent the condition. Verfiication and validation is important step to reduce or remove the errors [8]. The process can be seen in Figure 2.

Verification is a process to decide a simulation model has represented the conceptual model or not. The steps that can be done is review the model coding, check the logic output, check the animation and use tracing and debugging on software. Validation is the process to decide the 
conceptual has represent the real condition or not. To validate the model there are some steps like check the animation, compare with the real system, compare with other model, test with extreme condition, check the validation directly, test the historical data, sensitivity analysis, tracking and turing test.

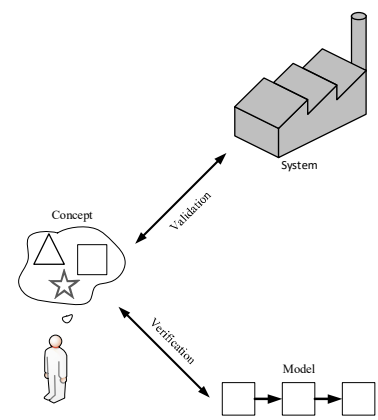

Fig 2. Verification and Validation [8]

\section{Methodology}

Motorcycles parking facilities in flat Penjaringan Sari 3 cannot accommodate all motorcycles owned by residents because of limited space and capacity. The existing parking area has no good arrangement so it is difficult for riders to park and de-park motorcycles. Another problem is there is no sign in parking area to manage all the motorcycles. Based on those problems, this research will design motorcycle parking area layout, parking slot, and motorcycles flow. The design will be run in simulation to prove how well this design if it is implemented.

There are primary data and secondary data collected in this research. Primary data come from observation to existing layout at the motorcycle parking area, layout of the flat surrounding, number and types of motorcycles owned by occupant, arrival time of the motorcycles, and time for motorcycle to enter and exit the parking area. For secondary data is reference about standard parking slot of motorcycles, comes from Planning and Operation Manual Parking Facilities that is issued by the Directorate General of Land Transportation [2].

\section{Results and Discussion}

By using software EasyFit Professional 5.2, we checked the data distribution. The data is time to enter and park the motorcycle and time between arrival. The distribution used in this study for initial layout is $\mathrm{T}(47954,60.07,60.07)$, for new layout is $(0.72545,1.0371,16: 57,18367)$, and the time of arrival is (166.15).

Based on the observation, the dimension of motorcycle parking slot is $200 \mathrm{~cm}$ long and $75 \mathrm{~cm}$ wide, but it is also contained parking line that has width $10 \mathrm{~cm}$. So, the total dimension of motorcycle parking slot as can be seen in Figure 3 is $200 \mathrm{~cm}$ long and $85 \mathrm{~cm}$ wide. The parking slot for every motorcycle will has dimension $175 \mathrm{~cm}$ long and $70 \mathrm{~cm}$ wide, with free space $5 \mathrm{~cm}$ at the front, $20 \mathrm{~cm}$ in the rear and $2.5 \mathrm{~cm}$ on right and left side.
There are two capacities that will be set for the new parking area. First is parking area consist of 145 motorcycles, this amount is based on the existing number of motorcycles that park in the flats parking area. Second is parking area that will be accommodate 297 motorcycles, because actually Surabaya City government as the operator allow maximum 3 motorcycles for each unit. Because there are 99 units in flats Penjaringan Sari 3, so there will be maximum 297 motorcycles.

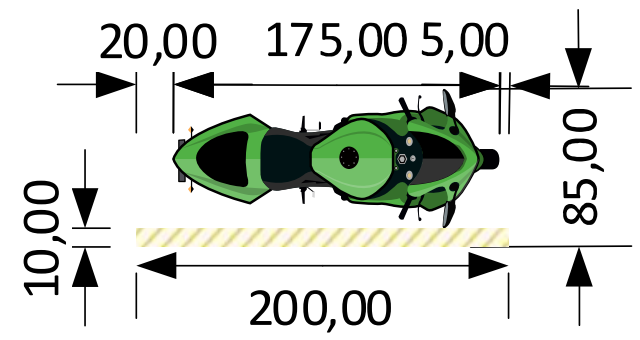

Fig 3. Satuan Ruang Parkir (SRP) for Motorcycle [2]

Another condition that must be set on parking area is exit and entrance must head to the 1 st floor and 2 nd floor because for now it is only one door with 2 meters wide. The aisle must be 1.6 meters for double way and 1 meter for one way. To make it clear, it needs sign like arrow to give direction for the riders. The new layout will use parking angle $90^{\circ}$ to accommodate more motorcycles.

By considering buildings construction per level for parking area requires free space upwards of basic floor of at least 2.5 meters on each floor, construction of vehicles ramp to second floor 2.5 meters high and distance flatness is 5 meters, calculation of the building strength that has number and dimensions of the column to be used, we can summary the required space area as shown in Table 1 .

Table 1. Summary of Alternative Capacity

\begin{tabular}{|c|c|c|c|c|}
\hline & $\begin{array}{c}\text { Alternati } \\
\text { ve 1 }\end{array}$ & $\begin{array}{c}\text { Alternati } \\
\text { ve 2 }\end{array}$ & $\begin{array}{c}\text { Alternati } \\
\text { ve 3 }\end{array}$ & $\begin{array}{c}\text { Alternati } \\
\text { ve 4 }\end{array}$ \\
\hline $\begin{array}{c}\text { Size } \\
\mathrm{m}^{2}\end{array}$ & 442.52 & 327.94 & 890.07 & 526.69 \\
\hline $\begin{array}{c}\text { Capaci } \\
\text { ty }\end{array}$ & 159 & 189 & 300 & 317 \\
\hline
\end{tabular}

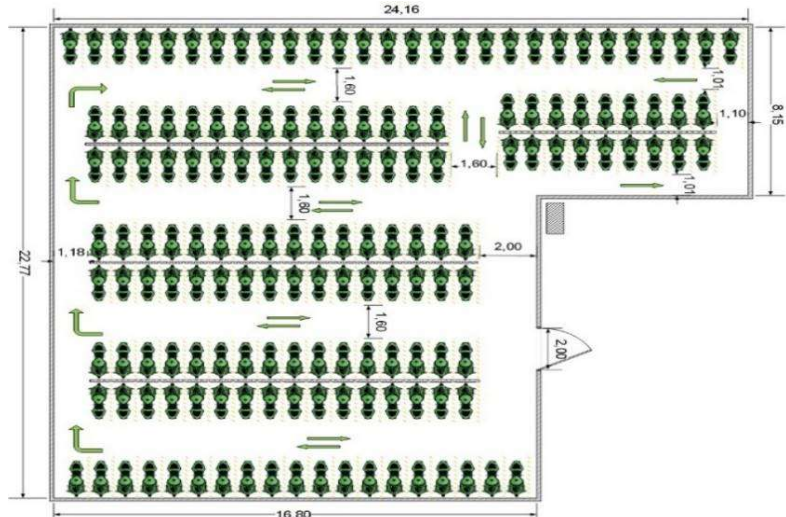

Fig 4. Layout and flow motorcycle for alternative 1 
Alternative 1 in Figure 4 is an alternative construction of the parking building for existing number of motorcycles, allocated on the first floor. It will use the yard as the parking area as permission given by Kota Surabaya City government. With the new layout it can accommodate 159 motorcycles, more than existing number of motorcycles. In Figure 5, alternative 2 is the construction of a parking deck with a capacity of 189 motorcycles, allocated into two floors. The land use is less than alternative 1 . We also made a regulation to separate female riders at first floor, and male riders at second floor. Alternative 3 in Figure 6 is the construction of a parking deck with a capacity of maximum 300 motorcycles that is allocated in one floor. Alternative 3 requires a land area of $890.07 \mathrm{~m}^{2}$ and located in two locations but still in flat's yard. Alternative 4 is the parking building with a highest capacity, 317 motorcycles, that is allocated into two floors. Alternative 4 in Figure 7 only require a land area of $526.69 \mathrm{~m}^{2}$, less than alternative 3 . The same regulation will be implemented in alternative 4 .

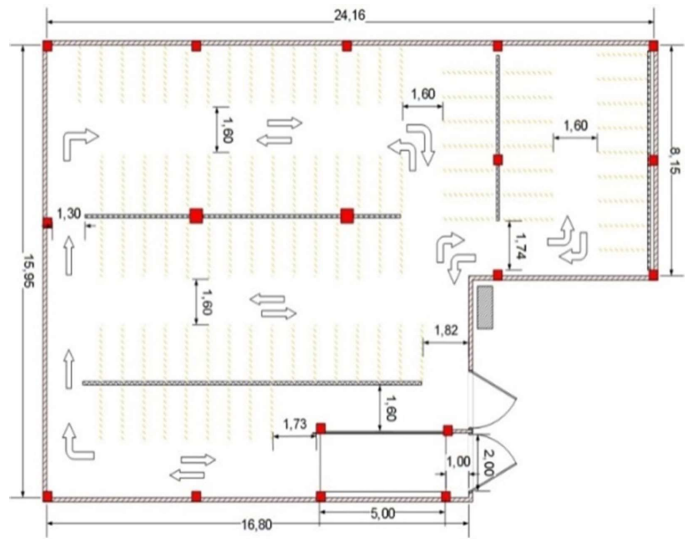

Fig 5. Layout and flow of motorcycles alternative 2

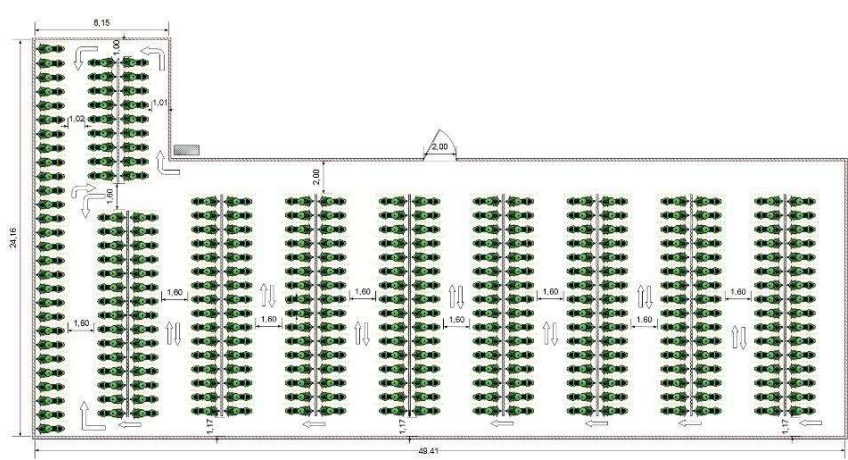

Fig. 6. Layout and flow motorcycle alternative 3

To create simulation model using ProModel Student Version 7, the components are location (entrance for the flats yard, entrance of flats, entrance of parking area), entities (motorcycle that goes to parking area, path networks from flats entrance to parking area and the surrounding), process, arrival (motorcycle that is came to entrance, and variable (parking slot capacity near to the exit door). The simulation has limitations and assumptions like the time taken for the ride of a motorcycle parking lot entrance to the second-floor parking area is 10 seconds and waiting time of the motorcycle for 8 hours.

For good simulation initial layout and the new layout each parking area is divided into 3 parts. The first is near or the closest location with the entrance. Usually it is become favorite for the riders because it is easier to park and de-park, and also it is needing less time to go out. But because of limited space, usually it only consists for few motorcycles. Second is medium location, not so far from the entrance and needs the bigger space. Third is far that has similar percentage with the near area but has the farthest location in parking area. The division is based on the assumptions based on observation that the favorite parking slot is within 5 meters in the parking area, then it continues to medium and far area. The division of the distance and the size of each location can be seen in Table 2.

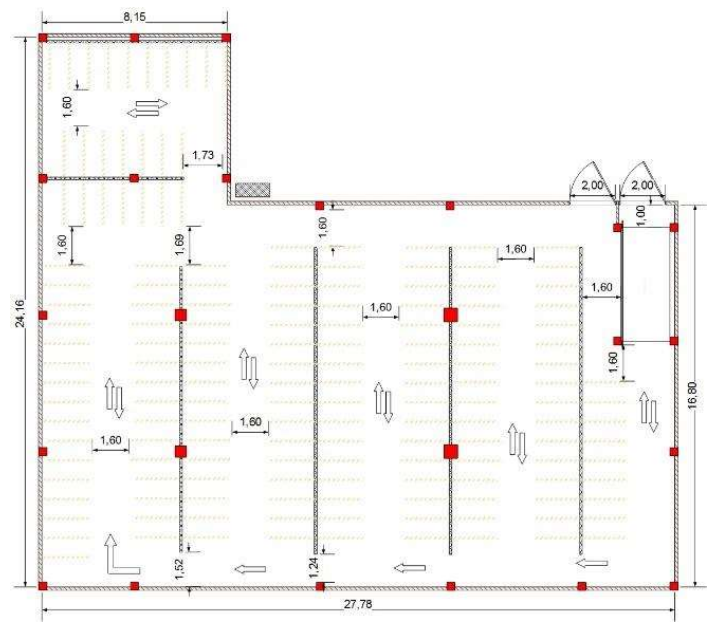

Fig. 7. Layout and flow motorcycle for alternative 4

Based on the simulation results showed that improvements of parking layout make a motorcycle out of the slot to be faster when compared to the initial state. At the beginning of the simulation results motorcycles time required to get out of his parking slot 56.118 seconds, while for each alternative as shown in Table 3.

The simulation is validated and verified using Minitab 17 with a significance level of testing $(\alpha)$ of $5 \%$. The results of the validation stated that the model simulation with real conditions valid or $\mathrm{H}_{0}$ is accepted. Testing to model alternatives give prove that model alternatives have shorter time for park and de-park from the parking area if it is compared with the initial model.

\section{Conclusion}

Limited parking space at Rusunawa Penjaringan Sari 3 Surabaya must be consider a serious problem for he residents. The existing number of motorcycles still cannot accommodate by the facility, moreover if the requirement is getting higher. To support the needs this research will proposed a new design of parking area that it used to be in area people walking. We designed four alternative of parking layout that consider the peak and non peak time, 
and also follow the rule by Indonesia Government. The result is very good, now riders can save the time until $75 \%$ effectively, and the capacity is getting bigger. Vallidation and verification have done and guarantee the simulation represent the real data. The model still has the assumptions like capacity distribution percentage or assumptions about favorite area. It is better to get the real data. However, this paper has offered some alternatives that can be used as motorcycle parking area.

Table 2. Capacity Distribution of Parking Area

\begin{tabular}{|c|c|c|c|c|c|}
\hline & \multicolumn{2}{|c|}{ Under Building } & \multicolumn{3}{|c|}{ Outside of the Building } \\
\hline & $\begin{array}{c}\text { Radius } \\
(\mathrm{m})\end{array}$ & $\begin{array}{c}\text { Capacity } \\
\text { (units) }\end{array}$ & $\begin{array}{c}\text { Radius } \\
\text { (m) }\end{array}$ & \multicolumn{2}{|c|}{$\begin{array}{c}\text { Capacity } \\
\text { (units) }\end{array}$} \\
\hline $\begin{array}{l}\text { Near } \\
(30 \%)\end{array}$ & 6.1 & 16 & 4,63 & & 14 \\
\hline $\begin{array}{r}\text { Medium } \\
(45 \%) \\
\end{array}$ & 15.3 & 28 & 11.58 & & 20 \\
\hline \multirow[t]{3}{*}{$\operatorname{Far}(25 \%)$} & 20.4 & 14 & 15.45 & & 8 \\
\hline & \multicolumn{2}{|c|}{ Alternative 1} & \multicolumn{3}{|c|}{ Alternative 2} \\
\hline & $\begin{array}{l}\text { Radiu } \\
\text { s (m) }\end{array}$ & $\begin{array}{l}\text { Capacit } \\
\text { y (units) }\end{array}$ & $\begin{array}{l}\text { Radius } \\
\text { (m) }\end{array}$ & $\begin{array}{c}\text { Capac } \\
\text { ity Lt. } \\
1\end{array}$ & $\begin{array}{c}\text { Capa } \\
\text { city } \\
\text { Lt. } 2\end{array}$ \\
\hline $\begin{array}{l}\text { Near } \\
(30 \%)\end{array}$ & 3.42 & 13 & 4.79 & 4 & 4 \\
\hline $\begin{array}{l}\text { Medium } \\
(45 \%)\end{array}$ & 8.54 & 104 & 11.97 & 64 & 54 \\
\hline \multirow[t]{3}{*}{ Far $(25 \%)$} & 11.39 & 42 & 15.95 & 27 & 36 \\
\hline & \multicolumn{2}{|c|}{ Alternative 3} & \multicolumn{3}{|c|}{ Alternative 4} \\
\hline & $\begin{array}{c}\text { Radiu } \\
\text { s (m) }\end{array}$ & $\begin{array}{l}\text { Capacit } \\
\mathrm{y} \text { (units) }\end{array}$ & $\begin{array}{l}\text { Radius } \\
\text { (m) }\end{array}$ & $\begin{array}{c}\text { Capac } \\
\text { ity Lt. } \\
1\end{array}$ & $\begin{array}{c}\text { Capa } \\
\text { city } \\
\text { Lt. } 2\end{array}$ \\
\hline $\begin{array}{c}\text { Near } \\
(30 \%)\end{array}$ & 7.11 & 22 & 8.33 & 15 & 30 \\
\hline $\begin{array}{c}\text { Medium } \\
(45 \%)\end{array}$ & 17.78 & 142 & 20.84 & 101 & 74 \\
\hline $\operatorname{Far}(25 \%)$ & 23.71 & 136 & 27.78 & 43 & 54 \\
\hline
\end{tabular}

Table 3. Average Time Motorcycle Exit the Parking Slot

\begin{tabular}{|c|c|}
\hline Alternative & Time (sec) \\
\hline Alternative 1 & 17.342 \\
\hline Alternative 2 & 17.273 \\
\hline Alternative3 & 21.986 \\
\hline Alternative4 & 17.242 \\
\hline
\end{tabular}

\section{References}

1. J. A. Stark, Parking Lots: Where Motorists Become Pedestrians. Albany University, (2012)

2. Direktorat Jenderal Perhubungan Darat, Pedoman Perencanaan dan Pengoperasian Fasilitas Parkir, Jakarta: Direktorat Jenderal Perhubungan Darat, (1998)

3. Menteri Perhubungan Republik Indonesia, Peraturan Menteri Perhubungan Republik Indonesia Nomor PM 13 Tahun 2014, Jakarta, (2014)

4. T. J. Kakiay, Pengantar Sistem Simulasi, Andi Publishing, Yogakarta, (2004)
5. A. Law, Simulation Modeling \& Analysis, Boston : McGraw Hill, 2007. Vol. IV, (2007)

6. M. Arifin, Simulasi Sistem Industri, Yogyakarta : Graha Ilmu, (2009)

7. J. M. Harris, Y. Dessouky, A Simulation Approach for Analyzing Parking Space Availability at A Major University, Proceedings of the Winter Simulation Conference, (1997)

8. C. Harrell, K. G. Biman, B. O. Royce, Simulation Using ProModel, New York : McGraw-Hill, (2003) 